\title{
Influence of chitosan addition on quality properties of vacuum-packaged pork sausages
}

\author{
Influência da adição de quitosana sobre a qualidade de salsichas embaladas a vacuo
}

\author{
Mario GARCÍA ${ }^{1, *}$, Raúl DÍAZ ${ }^{1}$, Felicidad PUERTA², Tatiana BELDARRAÍN , Juan GONZÁLEZ ${ }^{3}$ Iris GONZÁLEZ³
}

\begin{abstract}
The aim of the study was to evaluate the influence of the chitosan addition on the quality of vacuum packaged pork sausages. A variant of the product was elaborated with $1 \%(\mathrm{w} / \mathrm{w})$ of chitosan in lactic acid solution at $1 \%(\mathrm{v} / \mathrm{v})$ and it was compared to a control. Sausages were mechanically stuffed and manually conformed and vacuum packaged. Sausages were stored at $4{ }^{\circ} \mathrm{C}$ and microbiological evaluations, $\mathrm{pH}$ measurements, texture profile analysis and sensorial evaluation were performed. The chitosan addition in the formulation of the sausages did not reduce the microbiological counts. The $\mathrm{pH}$ values obtained in all samples were similar, which suggests that the chitosan addition did not influence the $\mathrm{pH}$ values of sausages. The added chitosan did not affect significantly $(\mathrm{p} \leq 0.05)$ the results of the texture profile analysis and sensorial attributes and therefore, the overall acceptance of the sausages.

Keywords: pork sausages; meat products; chitosan; microbiological quality; sensory quality; storage.
\end{abstract}

\section{Resumo}

O objetivo do estudo foi avaliar a influência da adição de quitosana sobre a qualidade de salsichas embaladas a vácuo. Elaborou-se uma variante do produto com $1 \%(\mathrm{~m} / \mathrm{m})$ de quitosana adicionada em dissolução de ácido láctico a $1 \%$ (v/v) e manteve-se um lote controle sem adição de quitosana. Formaram-se peças mediante torção manual e envasadas a vácuo. Determinaram-se, durante o armazenamento a $4{ }^{\circ} \mathrm{C}$, vários parâmetros de qualidade: avaliações microbiológicas, $\mathrm{pH}$, análise do perfil de textura e avaliação sensorial mediante a análise descritiva quantitativa. A adição de quitosana na formulação das salsichas não reduziu os conteúdos microbiológicos e os valores de pH obtidos em todas as amostras foram similares, o que sugere que a adição de quitosana não influencia os valores de $\mathrm{pH}$ das salsichas. A adição de quitosana não afetou significativamente $(\mathrm{p} \leq 0,05)$ os valores de textura nem as análises sensoriais estudadas mantendo, portanto, a qualidade do embutido.

Palavras-chave: salsichas; produtos cárneos; quitosana; qualidade microbiológica; qualidade sensorial; armazenamento.

\section{Introduction}

Chitosan, a linear polymer of 2-amino-2-deoxy- $\beta$-D-glucan, is a deacetylated form of chitin, a naturally occurring cationic biopolymer (LIN; ZHAO, 2007; AIROLDI, 2008). It occurs as a shell component of crustaceans (crab and shrimp), as the skeletal substance of invertebrates, and as the cell wall constituent of fungi and insects. Applications of chitosan include as flocculating agent, clarifier, thickener, gas-selective membrane, coating material, promoter of plant disease resistance, woundhealing factor agent, and antimicrobial agent (DONG et al., 2000; GARCÍA, 2008; GARCÍA et al., 2008). Recently, use of chitosan was approved by European Pharmacopoeia (COUNCIL OF EUROPE EUROPEAN, 2002, 2005) for its application in pharmaceutical forms.

Chitosan exhibits in vitro antimicrobial activity against a range of foodborne microorganisms and consequently has attracted attention as a potential natural food preservative (DARMADJI; IZUMIMOTO, 1994; FANG; LI; SHIH, 1994; ROLLER; COVILL, 2000; ROLLER et al., 2002;
SHAHIDI; ARACHCHI; JEON, 1999; SIMPSON et al., 1997; SUDARSHAN et al., 1992; WANG, 1992).

The objective of the study was to evaluate the influence of the chitosan addition on the quality of vacuum-packaged pork sausages.

\section{Materials and methods}

\subsection{Sample preparation}

Refrigerated lean pork and frozen pork backfat were obtained within 72 hours of slaughtering from a local meat packer and ground twice through a 9 and a $3-\mathrm{mm}$ plate, respectively. An emulsion-type pork product was prepared using ground meat, $\mathrm{NaCl}$, ice, pork backfat, trisodium phosphate, sugar, monosodium glutamate, sodium nitrite, and spicemix. Chitosan oligomer $\left(1 \%\right.$, molecular weight $=1.23 \times 10^{6}$ and $85.33 \%$ degree of deacetylation, Biomaterials Center, University

Recebido para publicação em 11/3/2009

Aceito para publicação em 7/7/2009 (004081)

${ }^{1}$ Pharmacy and Food Institute, University of Havana, Ave. 23, 21425, CP 13600,La Habana, Cuba, E-mail: mariog@ifal.uh.cu

${ }^{2}$ Meat Products Enterprise Ciego de Ávila, Cuba

${ }^{3}$ Food Industry Research Institute. Carretera al Guatao, Km 3 1⁄2, CP 19 200, La Habana, Cuba

${ }^{*}$ A quem a correspondência deve ser enviada 
of Havana, Cuba) was added to the treated products. Lean pork, salt and phosphate were placed in a silent cutter (MAINCA, Mod. 2130, Spain), mixed for about 1 minute after which $50 \%$ of the ice was added and mixed at high speed. When the temperature of mixture decreased around $1-2{ }^{\circ} \mathrm{C}$, ground pork backfat was added and mixed until the temperature of mixture reached $10{ }^{\circ} \mathrm{C}$. The remainder, $50 \%$ of the ice and other spices were added and mixed until the temperature of the mixture reached $13{ }^{\circ} \mathrm{C}$. Total emulsification time was about 10 minutes and processing room temperature was $13{ }^{\circ} \mathrm{C}$. The sausages were stuffed (MAINCA, Mod. 3763, Spain) into a fibrous casing $\left(2.0 \mathrm{~cm}\right.$ of diameter, NaloBar, Spain), dried $\left(50{ }^{\circ} \mathrm{C}\right.$ for 20 minutes), smoked $\left(60^{\circ} \mathrm{C}\right.$ for 30 minutes) using sawdust, and cooked to $71^{\circ} \mathrm{C}$ of internal temperature (about 1 hour) using a smokehouse. The cooked sausage was water-spray cooled for 5 minutes and dried at room temperature for 30 minutes. All samples (250 $\mathrm{g}$ in each bag) were vacuum-packaged in oxygen-impermeable polyester/polyethylene bags $(30 \times 40 \mathrm{~cm})$ (Tables 1 and 2) using a vacuum packaging machine. The samples were stored for 26 days at $4{ }^{\circ} \mathrm{C}$ until analysis.

\subsection{Microbiological evaluation and $\mathrm{pH}$}

A 10-g sample and $90 \mathrm{~mL}$ of sterilized distilled water were homogenized. The homogenate was serially diluted with sterilized distilled water and the dilutions were spread on the specific medium in aerobic conditions. Total aerobic bacteria ( $35 \pm 1{ }^{\circ} \mathrm{C}, 48$ hours), (NORMA CUBANA-INTERNATIONAL ORGANIZATION FOR STANDARDIZATION, 2003), coliform bacteria counts ( $37 \pm 1{ }^{\circ} \mathrm{C}, 48$ hours), (NORMA CUBANA-INTERNATIONAL ORGANIZATION FOR STANDARDIZATION, 2002a) and psychrophilic bacteria (4- $\left.6^{\circ} \mathrm{C}, 10 \mathrm{~d}\right)$, (NORMA CUBANA, 1982a) were performed with plate count agar (PCA, Biocen, La Habana, Cuba). The violet red bile glucose agar (VRBGA, Biocen) and malt extract agar (MEA, Biocen) were used to grow Enterobacteriaceae $\left(37^{\circ} \mathrm{C}\right.$,

Table 1. Base pack weight and thickness of complex film layers $(\mathrm{n}=10)$.

\begin{tabular}{lcrc}
\hline \multicolumn{1}{c}{ Parameter } & $\begin{array}{c}\text { External } \\
\text { layer }\end{array}$ & $\begin{array}{c}\text { Intermediate } \\
\text { layer }\end{array}$ & Internal layer \\
\hline Weight/unit area $\left(\mathrm{g} \cdot \mathrm{m}^{-2}\right)$ & $19.2(1.2)$ & $3.9(0.5)$ & $46.2(2.8)$ \\
Thickness $(\mu \mathrm{m})$ & $22.4(0.8)$ & $11.0(2.2)$ & $77.3(2.0)$ \\
\hline
\end{tabular}

Table 2. Water vapor and oxygen permeability, and thermal sealing resistance.

\begin{tabular}{lcc}
\hline \multicolumn{1}{c}{ Parameter } & Mean & $\begin{array}{c}\text { Standard } \\
\text { deviation }\end{array}$ \\
\hline $\begin{array}{l}\text { Water vapor permeability }\left(\mathrm{g} / \mathrm{m}^{2} \mathrm{~d}\right) \text { at } \\
23^{\circ} \mathrm{C} \text { and } 85 \% \text { relative humidity }\end{array}$ & 2.9 & 0.6 \\
$\begin{array}{l}\text { Gas permeability }\left(\mathrm{cm}^{3} / \mathrm{m}^{2} \mathrm{~d}\right) \mathrm{a} 25^{\circ} \mathrm{C} \\
\text { Heat seal resistance }(\mathrm{N} / 15 \mathrm{~mm})\end{array}$ & 42.2 & 3.1 \\
$\quad \begin{array}{l}\text { Heat seal of three sides bag } \\
\text { Heat seal of closing bag } \\
\text { (vacuum-packaging manual machine) }\end{array}$ & 22.1 & 1.0 \\
\hline
\end{tabular}

24 hours), (NORMA CUBANA, 1982b) and fungi and yeasts $\left(30^{\circ} \mathrm{C}, 48-72\right.$ hours), (NORMA CUBANA-INTERNATIONAL ORGANIZATION FOR STANDARDIZATION, 2002b), respectively. Colony forming units (CFU) per gram in plates were counted, at a dilution giving 30-300 CFU per plate, with Micro Counter.

The $\mathrm{pH}$ was measured using a $\mathrm{pH}$ meter (Metrohm Herisau, Mod. E-510) according to ISO 2917 (INTERNATIONAL ORGANIZATION FOR STANDARDIZATION, 1999).

\subsection{Texture profile analysis}

The sausage prepared from different treatment combinations was cut into $2-\mathrm{cm}$ thick pieces, placed on the target plate and radially compressed at $25^{\circ} \mathrm{C}$. The two-bite compression test was conducted with a Universal Texture Analyzer (Instron, Model 1140, USA) as described by Bourne (1978). With a cylindrical probe, $75 \%$ compression was achieved and then, from the graphics, hardness, springiness, cohesiveness, gumminess and chewiness were calculated.

\subsection{Sensory evaluation}

Modified Quantitative Descriptive Analysis (STONE et al., 1974) was used to evaluate sensory qualities of the sausage. Five trained panelists evaluated products over a structured scale of $10 \mathrm{~cm}$ delimited at both ends. The sausage was reheated to a $70{ }^{\circ} \mathrm{C}$ internal temperature in an oven at $180{ }^{\circ} \mathrm{C}$ for about 15 minutes, sliced into $2-\mathrm{cm}$ thick pieces, and served to the judges. The sensory attributes used in the current study were flavor, color, texture, and overall acceptance.

\subsection{Statistical analysis}

Experimental design used was 2 (chitosan treatment) $\times$ 1 (packaging) factorial and the whole experiment was replicated. Analyses of Variance were performed using STATISTICS software (STATSOFT, 1998) and the Duncan's multiple range tests were used to compare differences among mean values. Mean values were reported, and the significance was defined at $\mathrm{p} \leq 0.05$.

\section{Results and discussion}

\subsection{Microbiological results and pH measurements}

The results of microbiological analyses of the sausages during the 26-days storage period are presented in Table 3 . The addition of chitosan to the emulsion-type sausage did not reduce the number of microorganisms. The results of microbiological analyses of the sausages confirmed earlier results (YOUN et al., 1999; JO et al., 2001), showing that chitosan addition did not improve the microbiological quality of sausages.

After 14 days of storage at $4{ }^{\circ} \mathrm{C}$ the total viable counts were not significantly different, in the samples treated with $1 \%$ chitosan and the control samples, and total viable counts increased gradually in all samples during storage. An increase 
Table 3. Microbial population changes $\left(\log \mathrm{CFU} \cdot \mathrm{g}^{-1}\right)$ of pork sausage prepared with and without chitosan oligomer.

\begin{tabular}{|c|c|c|c|c|c|c|c|}
\hline Treatments & $\begin{array}{c}\text { Storage } \\
\text { period }(\mathrm{d})\end{array}$ & $\begin{array}{c}\text { Total aerobic } \\
\text { bacteria }\end{array}$ & $\begin{array}{c}\text { Coliform } \\
\text { bacteria }\end{array}$ & $\begin{array}{c}\text { Entero- } \\
\text { bacteriaceae }\end{array}$ & Fungi & Yeast & $\begin{array}{c}\text { Psychrophilic } \\
\text { bacteria }\end{array}$ \\
\hline \multirow[t]{3}{*}{ Control } & 7 & 1.8 & 1 & 1 & 1 & 1 & 1.6 \\
\hline & 14 & 2.8 & 1 & 1 & 1 & 1 & 1.6 \\
\hline & 26 & 2.3 & 1 & 1 & 1 & 2.0 & 2.1 \\
\hline \multirow[t]{2}{*}{ Chitosan } & 7 & 1.5 & 1 & 1 & 1 & 1 & 1.8 \\
\hline & 26 & 3.1 & 1 & 1.3 & 1 & 2.1 & 2.0 \\
\hline
\end{tabular}

in total viable counts (approximately $1 \log$ cycle, $\mathrm{p}<0.05$ ) was observed in the samples treated with $1 \%$ of chitosan after 21 days of storage. However, after storage for 26 days the total counts in the all samples had not already exceeded the maximum levels acceptable $\left(10^{7} \mathrm{CFU} \cdot \mathrm{g}^{-1}\right)$ (INSTITUTE OF FOOD SCIENCE AND TECHNOLOGY, 1999). By contrast, the total counts of sausages without chitosan were below the maximum acceptable levels for 21 days. These results partially agreed with those of Darmadji and Izumimoto (1994), who reported that Staphylococci, coliform, Gram-negative bacteria, Micrococci, and Pseudomonas in meat during storage at $30{ }^{\circ} \mathrm{C}$ for 48 hours and $4^{\circ} \mathrm{C}$ for 10 days were inhibited by the presence of chitosan, and the results of Sagoo, Board and Roller (2002) and Georgantelis et al. (2007), who found that treatment with chitosan at a concentration of $0.3-0.6 \%$ and $1 \%$, respectively, increased the shelf-life of fresh pork sausages stored at chill temperatures from 7 to 15 days.

Different mechanisms have been proposed for the antimicrobial effects of chitosan. Interaction between positively charged chitosan molecules and negatively charged microbial cell membranes leads to the leakage of proteinaceous and other intracellular constituents (CHEN; LIAU; TSAI, 1998; PAPINEAU et al., 1991; SUDHARSHAN; HOOVER; KNORR, 1992; YOUNG; KOHLE; KAUSS, 1982). Chitosan also acts as a chelating agent that selectively binds trace metals and thereby inhibits the production of toxins and microbial growth (CUERO; OSUJI; WASHINGTON, 1991). It also acts as a water binding agent and inhibits various enzymes (YOUNG; KOHLE; KAUSS, 1982). Chitosan also has bioabsorbant activity (KNORR, 1991) and can absorb nutrients of bacteria and may inhibit their growth. Binding of chitosan with DNA and inhibition of mRNA synthesis occurs via chitosan penetrating the nuclei of the microorganisms and interfering with the synthesis of mRNA and proteins (HADWIGER et al., 1985; SUDHARSHAN; HOOVER; KNORR, 1992).

The $\mathrm{pH}$ changes in fresh pork sausages during chill $\left(4^{\circ} \mathrm{C}\right)$ storage are shown in Table 4. On the day of preparation the $\mathrm{pH}$ of all batches ranged between 5.7 and 5.8. These values were similar to those reported in previous studies (CLAUS; HUNT, 1991; JO et al., 2001; SANTOS et al., 2003) for pork sausages. There was a gradual increase in $\mathrm{pH}$ in all samples during
Table 4. Effect of chitosan on $\mathrm{pH}$ values of the experimental sausages during the 26-days storage period $(n=2)$.

\begin{tabular}{ccc}
\hline Storage period $(\mathrm{d})$ & \multicolumn{2}{c}{ Treatments } \\
\cline { 2 - 3 } & Control & Chitosan \\
\hline 0 & 5.70 & 5.80 \\
7 & 6.21 & 6.10 \\
14 & 6.26 & 6.34 \\
21 & 5.82 & 5.75 \\
26 & 5.85 & 5.90 \\
\hline
\end{tabular}

storage, probably due to the accumulation of basic compounds such as ammonia, derived from microbial action (NYCHAS; DROSINOS; BOARD, 1998). Throughout storage there was no significant difference $(\mathrm{p} \leq 0.05)$ in $\mathrm{pH}$ values between samples containing chitosan and control samples.

\subsection{Texture and sensory analysis}

The sensory scores for sausages with vacuum packaging are shown in Table 5. Statistical significance was not found $(\mathrm{p} \leq 0.05)$ among all sensory parameters measured of sausages treated with chitosan and control samples. None of the mechanical texture profile analysis showed any difference either (Table 6). Therefore, the addition of chitosan oligomer in the emulsion-type pork sausage product did not change its color, flavor, texture and overall acceptance in agreement with Jo et al. (2001). The acid taste detected by judges from the twenty-first day onwards in samples with chitosan added were in line with the decrease in $\mathrm{pH}$ values (Table 4), and could be due to the growth of lactic acid bacteria, indicated by the increase in total aerobic bacteria counts (Table 3), what can be explained by the slight effectiveness of chitosan to inhibit this kind of bacteria.

Table 5 showed the results of the texture profile analysis of pork sausages during the storage period. The data showed that both samples prepared with chitosan and control samples had similar behavior $(\mathrm{p} \leq 0.05)$ during storage, which indicates that differences among the evaluated attributes were not due to the chitosan addition. Youn et al. (1999) reported, 
García et al.

Table 5. Sensory scores of pork sausage prepared with chitosan oligomer $(n=5)$.

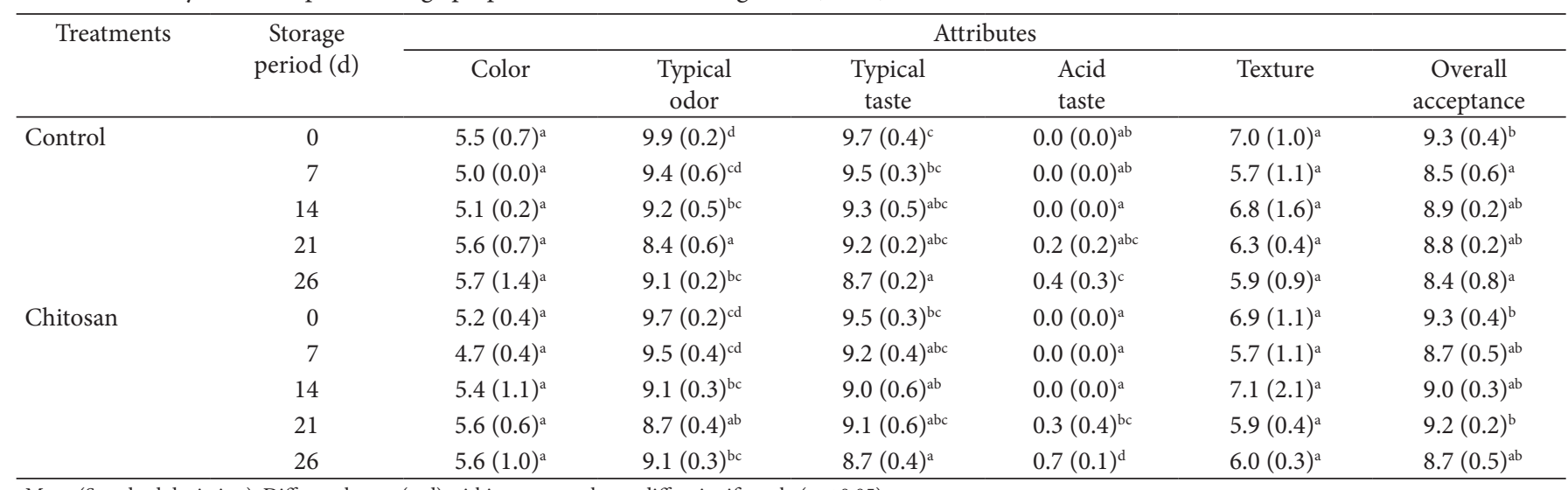

Mean (Standard deviation). Different letters (a-d) within a same column differ significantly ( $\mathrm{p} \leq 0.05)$.

Table 6. Texture profile analysis of pork sausage prepared with chitosan oligomer $(n=4)$.

\begin{tabular}{|c|c|c|c|c|c|c|}
\hline Treatments & $\begin{array}{c}\text { Storage } \\
\text { period }(\mathrm{d})\end{array}$ & Cohesiveness & $\begin{array}{c}\text { Gumminess } \\
\text { (kgf) }\end{array}$ & $\begin{array}{c}\text { Chewiness } \\
\left(\operatorname{kgf}_{*} \mathrm{~mm}\right)\end{array}$ & $\begin{array}{c}\text { Hardness } \\
\text { (kgf) }\end{array}$ & $\begin{array}{c}\text { Springiness } \\
(\mathrm{mm})\end{array}$ \\
\hline \multirow[t]{5}{*}{ Control } & 0 & $0.28(0.04)^{\mathrm{abc}}$ & $4.0(1.0)^{b c}$ & $34(9)^{b c}$ & $14.2(2.1)^{b c}$ & $8.4(0.2)^{b}$ \\
\hline & 7 & $0.31(0.02)^{b c d}$ & $4.7(0.3)^{c}$ & $39(3)^{b c}$ & $14.9(0.4)^{\mathrm{c}}$ & $8.2(0.2)^{\mathrm{b}}$ \\
\hline & 14 & $0.37(0.03)^{\mathrm{d}}$ & $4.1(0.6)^{b c}$ & $39(7)^{b c}$ & $11.2(1.0)^{\mathrm{a}}$ & $9.4(0.4)^{c}$ \\
\hline & 21 & $0.32(0.01)^{\mathrm{bcd}}$ & $4.1(0.7)^{\mathrm{bc}}$ & $40(5)^{b c}$ & $12.8(1.5)^{\mathrm{b}}$ & $9.5(0.4)^{c}$ \\
\hline & 26 & $0.24(0.05)^{\mathrm{a}}$ & $3.2(0.8)^{\mathrm{ab}}$ & $19(5)^{\mathrm{a}}$ & $13.6(0.7)^{b c}$ & $6.0(0.0)^{\mathrm{a}}$ \\
\hline \multirow[t]{5}{*}{ Chitosan } & 0 & $0.31(0.03)^{\mathrm{bcd}}$ & $4.9(0.8)^{\mathrm{c}}$ & $42(8)^{c}$ & $16.4(1.3)^{c}$ & $8.5(0.4)^{\mathrm{b}}$ \\
\hline & 7 & $0.33(0.06)^{\mathrm{cd}}$ & $4.8(1.1)^{\mathrm{c}}$ & $42(10)^{c}$ & $14.2(0.9)^{\mathrm{bc}}$ & $8.9(0.7)^{\mathrm{bc}}$ \\
\hline & 14 & $0.34(0.01)^{\mathrm{cd}}$ & $3.7(0.2)^{\mathrm{ab}}$ & $31(1)^{\mathrm{b}}$ & $11.3(0.6)^{\mathrm{a}}$ & $8.5(0.7)^{\mathrm{b}}$ \\
\hline & 21 & $0.36(0.01)^{\mathrm{d}}$ & $3.6(0.3)^{\mathrm{ab}}$ & $35(4)^{b c}$ & $10.4(0.9)^{\mathrm{a}}$ & $9.6(0.2)^{c}$ \\
\hline & 26 & $0.27(0.02)^{\mathrm{ab}}$ & $3.6(0.5)^{\mathrm{ab}}$ & $30(5)^{\mathrm{b}}$ & $14.1(0.5)^{\mathrm{bc}}$ & $8.2(0.2)^{\mathrm{b}}$ \\
\hline
\end{tabular}

Mean (Standard deviation). Different letters (a-d) within a same column differ significantly ( $\mathrm{p} \leq 0.05)$.

however, that the hardness of the sausage increased by an increase in molecular weight of chitosan, and, especially, at the highest molecular weight $(120,000)$ increased viscosity which may cause adverse effect on processing. In our study, chitosan was of medium molecular weight, so it did not affect hardness.

\section{Conclusions}

The study showed that chitosan can be used in pork sausages without affecting texture and sensory attributes. Although the quality of the sausages with added chitosan was acceptable, the investigation of its activity in a range of food systems is still needed for successful application to meat products. Microbial growth was not inhibited by addition of chitosan to sausages and the $\mathrm{pH}$ values obtained in all samples were similar, which suggests that the chitosan addition did not influence these values.

\section{Acknowledgements}

The authors wish to thank the Food Industry Research Institute of the Ministry of Food Industry of Cuba.

\section{References}

AIROLDI, C. A relevante potencialidade dos centros básicos nitrogenados disponíveis em polímeros inorgânicos e biopolímeros na remoção catiônica. Química Nova, v. 31, n. 1, p. 144-153, 2008.

BOURNE, M. C. Texture profile analysis. Journal of Food Technology, v. 32, n. 7, p. 62-68, 1978.

CHEN, C. S.; LIAU, W. Y.; TSAI, G. J. Antibacterial effects ofNsulfonated and $\mathrm{N}$-sulfobenzoyl chitosan and application to oyster preservation. Journal of Food Protection, v. 61, n. 9, p. 1124-1128, 1998.

CLAUS J.; HUNT, M. Low fat, high added-water bologna formulated with texture modifying ingredients. Journal of Food Science, v. 56, n. 3, p. 643-647, 652, 1991.

COUNCIL OF EUROPE EUROPEAN - COE. European Pharmacopoeia. 4 ed. Germany, 2002. p. 875-876.

COUNCIL OF EUROPE EUROPEAN - COE. European Pharmacopoeia. 5 ed. France, 2005. p. 1248-1249.

CUERO, R. G.; OSUJI, G.; WASHINGTON, A. N-carboxymethyl chitosaninhibition of aflatoxin production: role of zink. Biotechnology Letters, v. 13, n. 3, p. 441-444, 1991.

DARMADJI, P.; IZUMIMOTO, M. Effect of chitosan in meat preservation. Meat Science, v. 38, n. 2, p. 243-254, 1994.

DONG, Y. et al. Application of chitin/chitosan and their derivatives in food industry. Journal of Food Science and Technology, n. 5, p. 28-31, 2000.

FANG, S. W.; LI, C. F.; SHIH, D. Y. C. Antifungal activity of chitosan and its preservative effect on low-sugar candied Kumquat. Journal of Food Protection, v. 57, n. 2, p. 136-140, 1994. 
GARCIA, M. et al. Envasado activo de embutidos. Ciencia y Tecnología de los Alimentos, v. 18, n. 2, p. 1-7, 2008.

GARCIA, M. Películas y cubiertas de quitosana en la conservación de vegetales. Ciencia y Tecnología de los Alimentos, v. 18, n. 1, p. 71-76, 2008.

GEORGANTELIS, D. et al. Effect of rosemary extract, chitosan and a-tocopherol on microbiological parameters and lipid oxidation of fresh pork sausages stored at $4^{\circ} \mathrm{C}$. Meat Science, v. 76, n. 2, p. 172-181, 2007.

HADWIGER, L. A. et al. Chitosan both activates genes in plants and inhibits RNA synthesis in fungi. In: MUZZARELL, R. A. A. I.; JEUNIAUX, C.; GOODAY, G. W. (Eds.). Chitin in nature and technology. New York: Plenum Press, 1985. p. 209-222.

INSTITUTE OF FOOD SCIENCE AND TECHNOLOGY - IFST. Development and use of microbiological criteria for foods. London, 1999.

INTERNATIONAL ORGANIZATION FOR STANDARDIZATION. ISO 2917. Meat and meat products. Measurement of pH. [S.1.], 1999.

JO, C. et al. Quality properties of pork sausage prepared with watersoluble chitosan oligomer. Meat Science, v. 59, n. 4, p. 369-375, 2001.

KNORR, D. Recovery and utilization of chitin and chitosan in food processing waste management. Journal of Food Technology, v. 45, n. 1, p. 114-122, 1991.

LIN, D.; ZHAO, Y. Innovations in the development and application of edible coatings for fresh and minimally processed fruits and vegetables. Comprehensive Reviews in Food Science and Food Safety, v. 6, n. 3, p. 60-75, 2007.

NORMA CUBANA. NC 76-04-13. Determinación de microorganismos psicrófilos viables: método de ensayo. Cuba, 1982a.

NORMA CUBANA. NC 76-04-04. Determinación de enterobacterias totales. Cuba, $1982 \mathrm{~b}$.

NORMA CUBANA - INTERNATIONAL ORGANIZATION FOR STANDARDIZATION. NC-ISO 4832. Microbiología de alimentos para consumo humano y animal. Guía general para la enumeración de coliformes: técnica de placa vertida. Cuba, 2002a.

NORMA CUBANA - INTERNATIONAL ORGANIZATION FOR STANDARDIZATION. NC-ISO 7954. Microbiología de alimentos de consumo humano y animal. Guía general para la enumeración de levaduras y mohos: técnica de placa vertida a $25^{\circ} \mathrm{C}$. Cuba, 2002b.

NORMA CUBANA - INTERNATIONAL ORGANIZATION FOR STANDARDIZATION. NC-ISO 4833. Microbiología de alimentos de consumo humano y animal. Guía general para la enumeración de microorganismos: técnica de placa vertida. Cuba, 2003.

NYCHAS, G. J. E.; DROSINOS, E. H.; BOARD, R. G. Chemical changes in stored meat. In: BOARD, R. G.; DAVIES, A. R. (Eds.). The microbiology of meat and poultry. London: Blackie Academic and Professional, 1998. p. 288-326.

PAPINEAU, A. M. et al. Antimicrobial effect of water-soluble chitosans with high hydrostatic pressure. Food Biotechnology, v. 5, n. 1, p. 45-47, 1991.

ROLLER, S. et al. Novel combinations of chitosan, carnocin and sulphite for the preservation of chilled pork sausages. Meat Science, v. 62 , n. 2 , p. $165-177,2002$.

ROLLER, S.; COVILL, N. The antimicrobial properties of chitosan in mayonnaise and mayonnaise-based shrimp salads. Journal of Food Protection, v. 63, n. 2, p. 202-209, 2000.

SAGOO, S.; BOARD, R.; ROLLER, S. Chitosan inhibits growth of spoilage microorganisms in chilled pork products. Food Microbiology, v. 19, n. 2-3, p. 175-182, 2002.

SANTOS, R. et al. Durabilidad de salchichas empacadas al vacío. Alimentaria: Revista de Tecnología e Higiene de los Alimentos, n. 340, p. 41-44, 2003.

SHAHIDI, F; ARACHCHI, J. K. V.; JEON, Y. J. Food applications of chitin and chitosans. Trends in Food Science and Technology, v. 10, n. 2, p. 37-51, 1999.

SIMPSON, B. K. et al. Utilization of chitosan for preservation of raw shrimp (Pandalus boreallis). Food Biotechnology, v. 11, n. 1, p. 25-44, 1997.

STATSOFT. Statistics for Windows: release 5.1. Tulsa, USA, 1998.

STONE, H. et al. Sensory evaluation by quantitative descriptive analysis. Journal of Food Technology, v. 28, n. 11, p. 24-34, 1974.

SUDHARSHAN, N. R.; HOOVER, D. G.; KNORR, D. Antibacterial action of chitosan. Food Biotechnology, v. 6, n. 3, p. 257-272, 1992.

WANG, G. Inhibition and inactivation of five species of foodborne pathogens by chitosan. Journal of Food Protection, v. 55, n. 11, p. 916-919, 1992.

YOUN, S. et al. Effect on storage property and quality in meat sausage by added chitosan. Journal of Chitin and Chitosan, v. 4, n. 4, p. $189-195,1999$.

YOUNG, D. H.; KOHLE, H.; KAUSS, H. Effect of chitosan on membrane permeability of suspension cultured Glycine max and Phaseolus vulgaris cells. Plant Physiology, v. 70, n. 5, p. 1449-1454, 1982. 